Article

\title{
Entrepreneurial Cooperation Model between University and SMEs: A Case Study in Iran
}

\author{
Yazdan Moradi and Siamak Noori *
}

Industrial Engineering, Department of Industrial Engineering, Iran University of Science and Technology, Tehran 16846-13114, Iran; moradi_y@cmps2.iust.ac.ir

* Correspondence: snoori@iust.ac.ir; Tel.: +98-912-317-9361

Received: 4 July 2020; Accepted: 4 September 2020; Published: 3 November 2020

\begin{abstract}
The purpose of this research is to design and explain an entrepreneurial cooperation model between a university and small and medium-sized enterprises (SMEs). The main research question is as follows: What are the elements and conditions of development for entrepreneurial cooperation between the university and SMEs? In this study, a qualitative research method called grounded theory has been used. Data collection was conducted through a semi-structured interview, observation and, afterwards, library studies. The number of interviews continued until theoretical saturation was reached and, in each interview, the coding was modified and edited compared to the previous interview. Based on this model, the goals and motivations of entrepreneurial cooperation were introduced as the causal conditions, entrepreneurial cooperation between the university and SMEs was introduced as the main phenomenon, environmental issues and the entrepreneurship cooperation ecosystem were introduced as the background conditions, the context and infrastructure of entrepreneurial cooperation were introduced as the mediator condition and entrepreneurial cooperation consequence was introduced as the model consequence. The strategies of the entrepreneurship cooperation model between the university and SMEs are as follows: strategies related to the private sector and strategies related to the non-private sector.
\end{abstract}

Keywords: university and SMEs cooperation; grounded theory; Iran

\section{Introduction}

The cooperation between university and industry has been studied for many years and, in this regard, processing studies have been conducted. Between 2007 and 2018, more than 3000 studies were published in three scientific databases, including Web of Science (579 studies), Science Direct (2165 studies) and ERIC (427 studies). (ERIC is an online digital library of education research and information. ERIC is sponsored by the Institute of Education Sciences of the United States Department of Education). Both universities and industry have strived to achieve their goals through this cooperation.

In recent years, universities have seen their mission extended to what is commonly referred to in the literature as the "third mission" [1-4]; this "third mission" was defined by Secundo et al. [5] as "the generation, use, application and exploitation of knowledge with external stakeholders and society in general". Therefore, universities are increasingly expected to contribute to solve socio-economic problems [6]. University-Industry Collaboration as a means towards fulfilling the third mission is becoming an important point of attraction for people interested in the role of universities in a national economy [7].

University-Industry Collaboration (UIC henceforth) is multifaceted [8,9]. Indeed, a number of scholarly communities including management studies, the economics of innovation, industrial organization, the sociology of science, and science and technology policy have long been interested in the topic [9]. This multidisciplinary interest has led to various perspectives on studying and trying to 
understand UIC. The foci of the literature on UIC were first the conceptual aspects such as the form and scope of UlC, the formation of UIC, motivation for collaboration, outcomes of the collaboration as well as factors affecting the success of the collaboration and the underpinning theory $[9,10]$. Triple and quadruple helix models as the frameworks of UIC have also been discussed [11,12]. The recent literature on UIC has tended to focus on empirical studies depicting aspects and experiences with implementing UIC in specific countries [13-15], industries [16] and universities [6], or at scientific levels [17-20].

Universities are increasingly encouraged to take a leading role in economic development, particularly through innovation. Simultaneously, economic development policy itself is increasingly focused on small and medium-sized enterprises (SMEs), creating overlapping interactions in the roles of government policy, universities and SMEs and the processes of innovation creation and dissemination [21].

Research has shown that despite the importance of small and medium industry enterprises, the share of these industries' enterprises in the studies is small. In particular, the issue of entrepreneurial cooperation between SMEs and universities less attention has been paid. Table 1 shows the number of studies published on the Scopus site since 1990.

Table 1. The number of studies published on the Scopus site since 1990.

\begin{tabular}{ccc}
\hline Topic & Years & Number \\
\hline Entrepreneurial Cooperation between Universities & $1990-2020$ & 86 \\
Entrepreneurial Cooperation-Universities and SMEs & $1990-2020$ & 31 \\
Entrepreneurial Cooperation between Universities and SMEs & $1990-2020$ & 2 \\
Entrepreneurial Cooperation Model & $1990-2020$ & 0 \\
Entrepreneurial Cooperation Model between Universities and SMEs & $1990-2020$ & 0 \\
\hline
\end{tabular}

In Iran, 96 percent of industrial enterprises have been allocated to small and medium-sized enterprises, with a share of 42 percent of the country's industrial employment to themselves (SMEs in Iran, as in a number of European countries, mean enterprises that have less than 100 employees). Moreover, in the whole country, by the end of June 2016, the number of (large, medium and small) units having exploitation licenses were 88,352 units, of which 80,476 units were small and 4362 units were medium-sized enterprises. The necessity of this cooperation becomes more evident when, despite the large volume and the expansion and importance of small and medium-sized enterprises in the country's economy, many signs of bankruptcy and a lack of production prosperity in these enterprises are observed. Researchers and policymakers today believe that if the mentioned enterprises could exploit the potential existing in universities, it would be possible for them to survive; with better conditions, and by creating more value added, they could gain more wealth and ensure their continuous growth and development. However, no effective studies have been conducted about the cooperation between universities and small and medium-sized enterprises in the country, and the situation of cooperation between small and medium-sized enterprises and universities is not acceptable [22]. Therefore, the purpose of this research was to design an entrepreneurial cooperation model between universities and small and medium-sized enterprises. For this purpose, it was also necessary to identify the dimensions and components of cooperation between them. In other words, this research sought to answer the following two questions:

- What are the elements and conditions of development of entrepreneurial cooperation between universities and small and medium-sized enterprises?

- What is the proper conceptual model for entrepreneurial cooperation between universities and SMEs to strengthen and develop the entrepreneurship dimensions within them? 


\section{Theoretical Foundations of the Research}

\subsection{Components and Concepts of SME Cooperation with Environment}

\subsubsection{Types of Cooperation}

Generally, the concept of university and industry cooperation includes all the systematic activities that, by putting the facilities of university and industry together, try to carry out the tasks that each of these two institutions cannot perform alone. Lin [23] considers the goal of such cooperative relations between the university and the industry to access technologies, the development of removing border knowledge, the expansion of financial resources and the use of the innovative capabilities of universities. Bagherinejad [24] also believes that enterprises should establish a relationship with other knowledge-producing organizations such as universities, research and development centers, and others to develop innovation activities. The research results of Hanafizadeh et al.

One of the important types of cooperation is technological cooperation. Technological cooperation is an agreement that is deliberately and freely formed between two or more enterprises for the exchange, sharing and development of technology [25,26]. Refers to technological cooperation as one of the important sources of innovation. He believes that, in a new competitive atmosphere, organizations need innovative resources, and the advantages of the current competition and their internal resources are not enough for competitiveness and, on this basis, technological cooperation is considered as a tool to develop a competitive advantage and to eliminate the gap between the existing and desirable capabilities. The high risk of research and development, the shortage of financial resources and specialized human resources and the increasing complexity of technologies are among the causes that force small and medium-sized enterprises to exploit cooperation methods in the development of technologies [27]. Analysis of the internal strengths and weaknesses, as well as an investigation of the potential of the cooperation, can have an important role in the success or failure of this type of cooperation [28].

Another kind of cooperation is entrepreneurial cooperation. Entrepreneurial cooperation is an agreement that is deliberately and freely formed between two or more SMEs and the institution of a university to strengthen and develop the entrepreneurship dimensions within them. Investigation of the dimensions of entrepreneurship in the university evokes the concept of an entrepreneurial university. The entrepreneurial university is a concept that has been invented in recent decades in order to respond to today's communities' needs [29]. The entrepreneurial university is among the new approaches in higher education that have created the context for basic evolutions in the science and technology production system.

\subsubsection{Motivations of Cooperation}

The deepening of cooperation between universities and industry can be formed based on different motivations: financial benefits, scientific advancement and innovations are among these motivations [30]. Establishing tax privileges for enterprises in cases of cooperation with universities in the research and development arena, the emergence of new financial resources for the university and reducing its dependence on the government, the access of industries' enterprises to cheap laboratory equipment and the enjoyment of enterprises of cheap facilities, in cases of cooperation with universities, are part of the financial benefits obtained for the parties involved in the cooperation. [31] indicate that achieving a reputation by using the partner's name and access to skills and knowledge increases, respectively, are the most important motivations of the enterprises to create cooperation. Bjerregaard [32] also believes that learning from cooperation, the access to new information (for example, about data analysis methods), gaining profit and strengthening the position on the national and international markets through the development of new products are among the most important motivational factors of cooperation for the industry sector, while the development of new scientific tools, access to industrial 
data, the combination of complementary research and testing new scientific results in industry are the motivations of academic researchers for cooperation with industry.

\subsubsection{Stages and Approaches of Cooperation}

Bjerregaard [32] offers two strategies for creating mutual contact between the industry and the university, as follows: 1 . the exploratory approach, which has more applications in the areas in which research is more limited and individual relationships are also limited; 2 . the exploitative approach, in which the interpersonal relationships, such as the participation of an industrial researcher in training courses at a university, creates the connection. Companies, after redefining their current and future knowledge needs, define their strategy for interaction with a university [33]. Karlsson, Booth and Odenrick [34] believe that cooperation between a university and small and medium-sized enterprises is formed in three stages. First Stage (Start): Financial issues and personal motivations become important in the movement of academics towards cooperation. Second Stage (Organizing Cooperation): Creating a network and the presence of individuals and researchers in the communication network; trust between parties becomes important, as well as maintaining self-confidence and preventing the emergence of humiliation on the other side using the experiences of SME employees. Third Stage (Designing and Developing Cooperation): Modifying the organizational structure of the university and using scholarship. They also refer to mutual trust as a key factor in the formation and continuation of cooperation. Buganza, Colombo and Landoni [35] also believe that the cooperation of small and medium-sized enterprises with universities to develop a new product can be done in three phases: 1-research, 2-development and 3-testing. At first, the enterprise cooperates with the university in cases such as testing in which the duties are specific and can easily be defined, and only after positive experiences in this cooperation do they enter into more complex trust-based relationships such as research and development, which are independent of the SME's size and industry. Cooperation at the testing stage, on the one hand, affects two aspects: 1-reducing the total cost of research and development cooperation and 2-increasing the effectiveness of cooperation. In addition to the above points, if the enterprise has successful cooperation with a university in the research phase, the cooperation continues in the development and testing phases too.

\subsubsection{The Scope of Cooperation}

Chiesa [36], in a framework presented to help choose the appropriate cooperation method, refers to the goal of cooperation, cooperation content, and the typology of partners as three effective factors in choosing a cooperation method and believes that, in choosing a cooperation method, all factors must simultaneously be considered. He also divides the cooperation methods among enterprises into four categories of acquisition, joint venture, joint cooperation and outsourcing.

Cooperation between a university and small and medium-sized enterprises can be classified from the perspective of relationship length. According to Izushi [37], the services of research institutions can be divided into: 1 -services with low information gaps, including product testing and evaluation using the equipment of the institution, open use of testing and the evaluation of equipment by users alone, and 2-services with high information gaps, including technical advice and guidance, engineer training, lectures, workshops, study groups organized by the institute and joint or customized research.

The role of intermediary institutions in relationships with a high information gap becomes prominent. Intermediary institutions, by transferring the demand of industry to universities on the one hand and familiarizing the industry with the scientific capabilities and human resources existing in universities on the other hand, contribute to the formation of relationship and cooperation between universities and industry [38].

\subsection{Comparison of Large Enterprises and SMEs with Regard to Cooperation with Universities}

Concerning the issue of cooperation with university, there are some differences between SMEs and large enterprises, although there are similarities: Shown in the Table 2. 
Table 2. Comparison of large enterprises and SMEs with regard to cooperation with universities.

\begin{tabular}{|c|c|c|}
\hline Topic & Large Enterprises & SMEs \\
\hline Cooperation Goals and Strategies & $\begin{array}{ll}- & \text { Tax exemption [10] } \\
- & \text { Meeting mutual needs [22] } \\
- & \text { Access to a widespread } \\
& \text { network of experts }[23,38] \\
- & \text { Focus on research and } \\
\text { development services [39] } & \text { Mid-term [22] }\end{array}$ & $\begin{array}{ll}- & \text { Tax exemption [10] } \\
\text { - } & \text { Recruitment and transfer of } \\
\text { - } & \text { human resources }[40,41] \\
\text { Focusing on the } \\
\text { complications of the existing } \\
\text { situation, short-term }[22,40]\end{array}$ \\
\hline Cooperation Forms and Methods & $\begin{array}{ll}\text { - } & \text { Formal communication } \\
\text { - } & \text { Direct communication } \\
\text { [10,40,42] } \\
\text { - } \quad \text { Type of research } \\
\text { collaboration }[22,40] \\
\text { - } \quad \text { The more positive the results } \\
\text { of the previous collaboration, } \\
\text { the more complex forms of } \\
\text { collaboration will be planned } \\
{[22,35]}\end{array}$ & 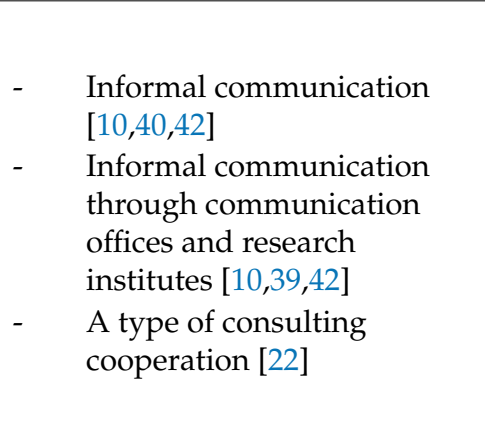 \\
\hline $\begin{array}{l}\text { Beginning and Continuity of } \\
\text { Cooperation }\end{array}$ & $\begin{array}{ll}\text { - } & \text { Relationships between } \\
\text { organizations [43] } \\
\text { - } \quad \text { Starting from low-risk } \\
\text { cooperation and continuing } \\
\text { to develop more cooperation } \\
{[22,35]} \\
\text { - } \quad \text { Large companies have more } \\
\text { advancement in cooperation } \\
\text { [44-46] }\end{array}$ & 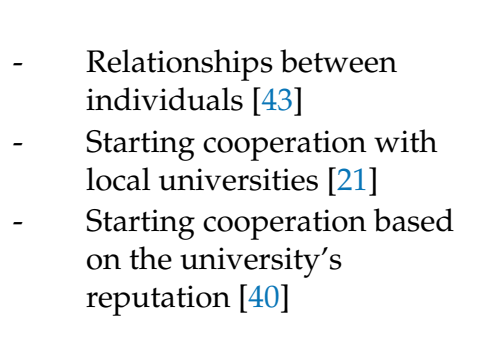 \\
\hline $\begin{array}{l}\text { Barriers and Challenges of } \\
\text { Cooperation }\end{array}$ & 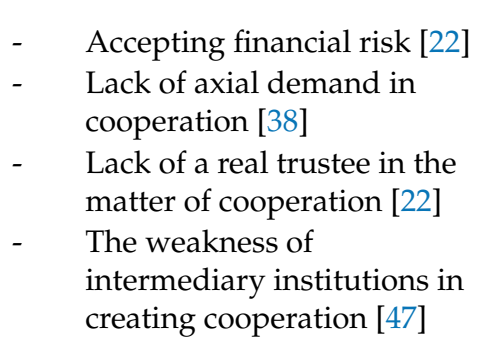 & $\begin{array}{l}\text { - } \quad \begin{array}{l}\text { The limitation of resource } \\
\text { [10,40,42] } \\
\text { - }\end{array} \text { Lack of specialized human } \\
\text { resources to large enterprises } \\
{[27,32]} \\
\text { - } \quad \text { Low attraction capacity } \\
\text { [48,49] } \\
\text { - The limitation of technical } \\
\text { facilities [50] }\end{array}$ \\
\hline
\end{tabular}

\section{A Review of the Research History}

Jones and Di Zubilki [40], by studying the interactions of universities and small industries in Australia in relation to the innovations of SMEs, state that research services, research partnerships, unofficial sources of ideas and scientific publications do not have a significant effect on the innovation of SMEs.

Goduscheit and Knudsen [50], in investigating the cooperation method of universities with SMEs in several countries, such as Denmark and Sweden, show that, in spite of the fact that the SMEs' cooperation experience, in particular with universities, strengthens the knowledge existing in SMEs, SMEs prefer to cooperate with research and technology offices rather than with universities, because hey see fewer obstacles in front of themselves and their cooperation is formed sooner.

Garcia-Perez-de-Lema et al. [43], in a study entitled "The Impact of Academic Companies on the Innovation and Performance Level of Spanish SMEs", concluded that relationships (cooperation) were divided into two categories of contractual and communicational. Contractual relationships are like research contracts, research and development projects, and innovation projects performed based on trust and informal individual relationships, and communicational (cooperation) relationships such 
as scholarships being provided to students by companies, business training, business consultation, the creation of business associations, as well as technical training are formed on the basis and foundation of common scientific and technological knowledge.

In the research of Plechero [42] in Italy, the role of local universities in improving the innovative performance of SMEs has been investigated. The aspects of the relationship with universities are 1-special professors and researchers, 2-special groups or faculties, 3-special university offices, (such as technology transfer offices), and 4-other cases. Moreover, the intermediary structure can be leveraged to guide the university's potential towards the needs of local companies to create a cooperative relationship. Of course, the role of intermediary structures is only at the beginning of the cooperation process. Another point is that the communications of companies with universities are often done through informal and direct communications with academics (professors and researchers) that are capable of responding to their needs.

In the research of Pickernell et al. [21], conducted in the United Kingdom, the cooperative options for SMEs are 1-universities, 2-other research institutions, 3-financial investors, 4-financial consultants, 5-business supporters 6-business consultants, and 7-other companies.

The cooperation of universities and Turkish SMEs, carried out by Temel et al. [51], indicates that information transfer in cooperation is carried out through face-to-face interaction between academic researchers and industrial researchers. On the other hand, cooperation with universities should occur at a certain level to reveal its benefits in SMEs growth. It is also necessary that, in cooperation, advantages are created and the university puts in a higher level of effort and commitment, otherwise the partner may decide to disrupt cooperation.

Regarding the internal studies in the field of cooperation between small and medium-sized enterprises with universities, as a few relevant studies have been done, the present research is new and innovative in this regard.

\section{Research Method}

In this research, grounded theory has been used to answer the research questions. However, as in grounded theory, the compilation of the research hypotheses is performed within the research and in the course of doing the research [52], so there are no hypotheses to be tested in this research that are specific to quantitative methods. Furthermore, to validity and reliability, the interview questions were modified from the supervisor's viewpoint and a final form was prepared; for data triangulation, data collection was also conducted in three ways: library studies, observation and interviews with a collection of academic experts and stakeholders (professors, students and employees of a university) and stakeholders of small and medium-sized enterprises (managers, employees and the owners of SMEs) in Iran during the years 2016-2018. (stakeholders in large enterprises such as SMEs include managers, employees and shareholders and the difference is in the characteristics and authorizations of these stakeholders). Sampling was done via the snowball (chains) purposeful sampling method. After performing 40 interviews (see Appendix A), the collected data reached theoretical saturation. Five industrial and national universities from three cities have been studied in the article. Also 15 numbers of all companies that participated in the "first SMEs capabilities exhibition" in Tehran-2018 were studied. They have varied in the type of products.

In the present study, data analysis was performed in three coding stages. In all three types of coding, the researchers constantly referred to the text of the interview and deleted some of the codes or added new codes. This reciprocal method continued until the research reached the stage of theoretical saturation.

\subsection{Open Coding}

In the present research, we used the row-by-row analysis method for open coding. In this method, the data were carefully studied, phrase by phrase and sometimes word by word. For this purpose, coding was done by writing the concepts in the margins of the text of the data (interviews). 
At this stage of open coding, the naming of concepts was done without any limitations in terms of the number of codes. Similar concepts were specified and then placed along with each other in one group. In fact, having completed the data conceptualization, similar concepts were grouped into a particular category.

\subsection{Axial Coding}

In the present research, by investigating the notes, six main categories were obtained. By axial coding, the relationship and proportions between categories can be specified. In fact, by specifying them, the phenomenon is located in the text in which the desired event occurs. In other words, the phenomenon is located within its own specific structure. This action is done by a paradigm pattern [53]. The categories of this research have been stated in six groups according to Table 1 and are as follows: causal conditions or categories, axial phenomena or categories, strategic categories, environmental conditions or categories, intermediary categories and consequence categories.

\subsection{Selective Coding}

In the selective coding stage, after several times studying and going back and forth between the data and the concepts of categories and codes, one category manifested itself more than the others in all the data and interviews. This category, which is the core or central category of the present study, entitled "Entrepreneurial Cooperation between Universities and SMEs", as an axial phenomenon, was located in the heart of other categories in the paradigm pattern. The reason for choosing this title is that all of the concepts and categories referred to it in some way, so, based on the axial phenomenon and axial coding, the components of entrepreneurial cooperation were extracted the selective coding stage.

\section{Findings}

\subsection{A Response to the First Research Question: What Are the Dimensions and Components of Entrepreneurial Cooperation between Universities and Small and Medium-Sized Enterprises?}

This was performed through the open coding process, and axial coding was performed based on the following descriptions. Data analysis in the grounded theory consists of three open, axial, and selective coding stages. The data were analyzed through the coding process and based on the systematic design of the grounded theory [53].

During open coding, the transcribed interview text was marked by live codes and repeated ideas were recognized. Coding and investigating repeated concepts continued to reach saturation, that is, until no new topic was found in the raw data [52].

In the next stage, the axial coding of these concepts was categorized in the general categories of causal conditions, strategies, and background and consequences, and they were theoretically interlinked in the form of a paradigmatic pattern. Selected coding in the theory offers an expression of the research process, including how to integrate the categories and refine them. The findings resulting from axial coding are shown in Table A2 in Appendix A.

\subsection{A Response to the Second Research Question: What Is the Proper Conceptual Model for Entrepreneurial Cooperation between Universities and Small and Medium-Sized Enterprises?}

This was performed through selective coding as shown in Figure 1. 


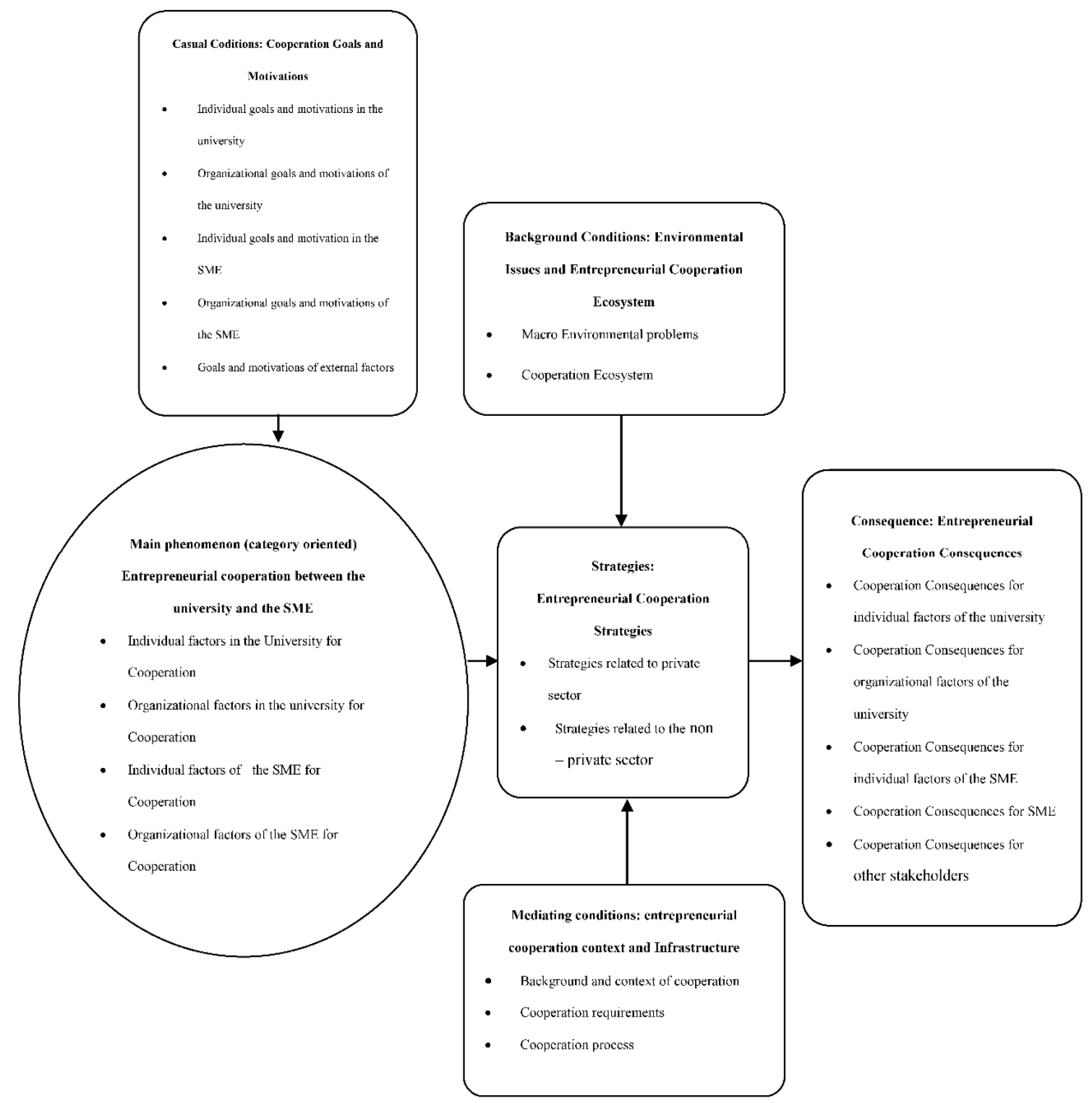

Figure 1. Paradigm model of cooperation between universities and SMEs.

\section{Discussion and Investigation}

\subsection{Causal Conditions (Goals and Motivations of Entrepreneurial Cooperation)}

Although, according to Lin [23] and Bjerregaard [32], universities show interest in cooperating with small and medium-sized enterprises and, in general, the industry also shows interest in terms of achieving the development of new scientific tool, accessing industrial data, the combination of complementary research and testing its results [30], financial benefits and scientific advancement, in the present research data, these cases are less observed and the strongest causes of cooperation result from individual goals and individual characteristics (both in universities and in SMEs). In other words, in the present situation, characteristics such as interest and the internal motivations of individuals have led to some cooperation. In the SMEs, tax privileges, financial benefits, scientific advancements and modern innovations [30], achieving university fame [31], finding solutions to problems [40], and tax exemptions [10] are the desired goals of cooperation, which, as stated, are less important to craftsmen. 


\subsection{Axial Category (Entrepreneurial Cooperation between Universities and Small and Medium-Sized Enterprises)}

In this section, the data are divided into two parts related to the individual and organizational factors of the university and also the individual and organizational factors of the SMEs. In order to investigate the individual and organizational factors within the university, identifying them, analyzing them and stakeholder participation (professors, students, university, employees) have a high degree of importance. Regarding the individual factors of universities, based on the collected data, the focus is currently on just one specific stakeholder at universities, the professors, while other stakeholders are not considered.

Regarding the organizational factors in universities, six cases, including useful and applied research, entrepreneurship and commercialization, entrepreneurial education, entrepreneurial programs and structures, professional management as well as university capabilities and facilities have been mentioned, which are consistent with the research of Aghajani et al [29]. The most important data appearing in this section are related to the article orientation problem, inapplicability, not being converted into the technology of research, the excessive weakness in teaching practical skills to students, the bureaucratic and inflexible structure of universities and the lack of responsiveness to the needs of craftsmen, the low authority of university chancellors, unprofessional management in universities, and the lack of full exploitation of the facilities and potential of universities.

Regarding the individual and organizational factors of SMEs for cooperation, it should be said that, in SMEs, the organization and the main stakeholder are summarized in the SME "manager/owner" (code 20), which is the source of the creation and continuity of cooperation. If they have entrepreneurial characteristics, and especially a positive attitude towards cooperation, cooperation takes place, otherwise cooperation will not take place. If the employees and family members of the manager/owner, as stakeholders, also have entrepreneurial individual characteristics and exploit their emotions and feelings towards the main stakeholder, who is the SME manager/owner, cooperation will definitely be effective (code 8). Of course, it should be mentioned that, in terms of organizational factors in SMEs, the research data refer to: (1) problems and needs; (2) programs and structures; and (3) the professional management of SMEs.

\subsection{Background Conditions (Environmental Issues and Entrepreneurial Cooperation Ecosystem)}

The country's macro environmental issues affect the entrepreneurial cooperation between universities and SMEs through four categories of administrative, cultural, political and economic issues. In administrative issues, there are injustices in referring industrial research projects to special professors, and the existence of bribery in administrative-financial interactions (code 38). Regarding cultural issues, statements such as "Our work culture has problem", "Being beneficiary of the decision makers in national projects", "The professors being satisfied with the status quo", "Preferring imports to production and manufacturing inside", which were expressed by the participants, reflect the country's cultural problems and issues. Of course, along with these problems, some other participants have mentioned the strengths of the country's human resources, such as commitment and Jihadi working. With regard to the political issues, especially in macro-issues and in macro rules and regulations, by changing the attitude of the responsible groups in the country and even the ministries and universities and the emergence of political changes, some national projects do not end successfully (code 37). Concerning economic issues, there are statements such as "The production task is a hard work and compared to the work of brokerage services, it has trivial profit" (code 28) and the "Economic promises of the authorities to support the SME is not realized" (code 31). Changes in the currency rate and supplying raw materials from abroad are also among the issues and problems putting pressure on SMEs and a reduction in their working capital affects their cooperation with universities (codes 21-33-35).

In the case of the cooperation ecosystem, which is the set of environmental factors above, in addition to guild societies and related institutions and centers, for various reasons, they are not in a good situation to create and complete the cooperation process. According to the participant codes 
35-36-37, growth centers, science and technology parks, research towns and similar intermediary centers have been associated with failure due to imitation and not completing the designed cycle.

\subsection{Mediating Conditions (Entrepreneurial Cooperation Infrastructure and Context)}

It is truly a very difficult task to create and continue cooperation between universities and industry in Iran, and it is associated with many obstacles and difficulties and one of the reasons for previous failures was also due to the same difficulties [22]. If a few examples of participants' statements are considered, this point can be clarified further: "Our previous experience in this field was unsuccessful" (codes 2-22-25-28), "We do not have a good experience about the topic of theses and internships" (code 8), "The subject of cooperation is a stereotypical and repetitive subject" (code 37). A statement that was heard in a large number of interviews indicates the repetitiveness of the subject and the fact that the desired results are not achieved, the difficulty and hardness of the work, the lack of preparedness for conditions and the lack of cooperation motivation (codes 9-30-35-36-40). The abundant involvement of university professors, as the most important stakeholders in universities, and also the abundant involvement of the managers/owners, as the main stakeholders in SMEs, do not offer any peace of mind in pursuing the issue of cooperation from the perspective of both parties. The existence of various goals, different perspectives and expectations about cooperation [32] are other barriers to cooperation (code 20).

Any cooperation has requirements. Budget, facilities, communication mechanisms and legal issues are among the most important data that appeared in the research as cooperation requirements. Budget is one of the most important factors that can create and maintain cooperation. According to the data, it is expected that this budget is funded by either the SMEs or via government support. However, for various reasons, they refuse to fund this budget unless they have confidence or assurance of the cooperation's results (codes 16-17).

Another requirement of cooperation is the existence of communication mechanisms. The following sentences explain the meaning of communication mechanisms better: "University and industry are unaware of the power and position of each other" (codes 23-31); "Academics do not know what is going on in the industry" (code 19); "The university door is not open for the arrival of craftsmen, and if a craftsman refers to the university, nobody is accountable to him" (code 40).

One of the most important and main problems in the field of cooperation is legal issues. "Legal issues are very important in cooperation", (code 16). Essentially, any cooperation is shaped in the form of a formal or informal agreement. The more serious and more important the work is, the more these agreements advance towards formalizing and signing cooperation contracts, memoranda of understanding and other forms of agreements. From the beginning of the cooperation process, and even before it, issues such as signing research contracts agreed by both parties, the fair division of (material and spiritual) consequences resulting from cooperation, pursuing administrative financial issues, legal issues (such as the establishment of a new company, etc.) and also to pursue governmental support, facilities and incentives are among the issues that are important for the cooperating parties to agree on. More explanations about how to meet the requirements of cooperation are presented in the following section.

\subsection{Entrepreneurial Cooperation Strategies}

The most important and basic question is what strategies exist to realize the desired phenomenon, namely "entrepreneurial cooperation between universities and SMEs"? What features should these strategies have so that, according to the participants, they are not repetitive and stereotypical? The answers to these questions, according to the interviewers, are stated below. Strategies should:

1. Be based on the power of the private sector and avoid relying on government sectors (codes 35-40).

2. Be self-driven and largely ignore the public budget (code 19). 
3. Be demand oriented and change based on the required (supply and demand) mechanisms (codes 16-40).

4. Consider risk taking, accountability and cultural differences (codes 5-6-16).

5. Be native and avoid emphasizing alien patterns (codes 15-24-30-34-35-37).

6. Adhere to the following topics and cases by creating and establishing cooperation between academic stakeholders and SME stakeholders: industrial clinics, SMEs diagnosing complications, launching demand-oriented startups, helping to develop new SME products, marketing (technology and products), making knowledge-based SMEs (codes 16-30-35).

7. Be executive and attract the will and desire of academic and public senior managers (codes 34-38).

With this explanation and based on the research data, the strategies are divided into two parts: strategies related to the private sector (two strategies), and strategies related to the non-private sector (two strategies).

\subsubsection{Strategies Related to the Private Sector}

Private Sector Agent (Intermediary) Model

Previously, we discussed the cooperation process, including the need for assessment, following up on necessary actions at the start of the cooperation, cooperation contracts, administrative-financial and legal issues of cooperation, commitments and guarantees, following up on and participation of all stakeholders, a fair share of cooperation consequences and, ultimately, continuity of cooperation. Another important question that must be asked is "by which individual or institution should this particular combination of various affairs be carried out, universities or SMEs?" The answer is abundantly clear: neither. The reason is that, so far, these actions have not been carried out by either of them. Either they do not want to, or cannot, or both. The most important strategy in this regard that can be taken into account in the country's current condition is to utilize private sector mediation intermediary agents and support them to fill the cooperation gap between the two types of institutions.

According to the data collected, for their success, the private sector agent needs to present a combination of 1 -supporting and facilitating administration, 2-scientific and technological mediation, 3-business and 4-investing in services both for the stakeholders of a university and the stakeholders of SMEs. These agents that are established in the form of private companies by a collection of interested, capable people with proper financial power will pursue the above goals.

The Model of New Emerging Knowledge-Based Company Establishment

Another strategy, referred to as the private sector strategy, is the strategy of establishing knowledge-based companies by academic stakeholders, based on which they will perform the commercialization of new technology. This strategy has a chain of components, such as growth centers, science and technology parks, research towns, and so on. In this regard, the exploitation of the capacity of "The law on the protection of knowledge based companies and institutions approved by the Islamic Consultative Assembly on 20 November 2010", is emphasized. Using the supports of the Vice Presidency for Science and Technology, the Innovation and Prosperity Fund and other governmental institutions are also being considered; thus, for more exploitation of the aforementioned support, the use of private sector agents' power (the first strategy) is recommended.

\subsubsection{Non-Private Sector Strategies}

\section{Jihad-Based Native Model}

In this strategy, which has been named the Jihad-based native model, the main focus is on particular individuals. The axis of this model is young, energetic, and jihadist university professors who are ready to show sacrifice and devote themselves in respect to the country's long-term development goals. The emphatic recommendation of this strategy is to start the work of research with the available 
facilities, even if this is only through small actions initially, in any possible conditions (codes 2-35), and, by the effort and persistence of the research team to complete the research, better outcomes can be achieved in the future. In this strategy, the role of the university will be to identify and completely support these individuals as a "support-oriented" university to achieve the desired goals.

\section{Support-Oriented University}

In this strategy, the university will be converted to a support-oriented university in order to achieve the goals of an entrepreneurial university. In this regard, the university is required to modify its structure and regulations in order to support other strategies such as the model of cooperation between private sector agents (intermediaries), knowledge-based companies and the Jihad-based native model. The regulations referred to during the interviews, which need to be modified, are as follows: 1 -the regulation of the attraction of academic members, 2-the regulation of the promotion of academic members, 3-regulation related to educational courses (skills-internship courses), especially at the postgraduate level (articles and theses), 4-the rules and regulations for supporting knowledge-based companies, 5-the necessity to compile regulations to support the private sector agents and their activities inside the university and 6-supportive regulations in respect to the Jihad-based native model.

\subsection{Entrepreneurial Cooperation Consequences}

\subsubsection{Consequences Related to the University Stakeholders}

As individual consequences in the university, and if entrepreneurial cooperation is created and continued between universities and SMEs, all academic stakeholders, in particular professors and, in the next stage, students and employees, will benefit from higher incomes, and will also receive awards and material and spiritual support. Among the immaterial advantages, acquiring skills and technology for professors and students, a reduction in the research activity risk, and also satisfying internal concerns and adhering to professional responsibilities in relation to them can also be named.

In the dimension of organizational consequences for the university, achieving the components of an entrepreneurial university can be mentioned. Moreover, the implementation of the stated strategies in the context of causal, background, and mediating conditions provides hope to the university that it performs a part of its social and professional responsibilities in order to respond to internal and external stakeholders. Furthermore, the results of implementing strategies can result in an improvement in the efficiency of university facilities and the creation of wealth and value added for themselves and their internal stakeholders. On the other hand, the students of a university benefit from the results of related measures with respect to learning skills, gaining entrepreneurial self-confidence, forming business teams and ultimately creating knowledge-based employment.

\subsubsection{The Consequences Related to the SMEs Stakeholders}

Helping to survive and grow SMEs is the most important consequence of implementing this model for SMEs. Although the individual and organizational consequences of SMEs are completely intertwined, SMEs and universities can be confident that if the cooperation chain is completed and the performance of strategic and corrective actions has always occurred during times of growth and prosperity, they will be far away from bankruptcy and entering a declining period. Moreover, in gaining more wealth and value added from the productivity of their own facilities, the application of knowledge-based methods in their own work and the use of new technologies for SMEs will not be far from the expectations. Furthermore, benefiting from tax, customs, insurance exemptions, etc., as well as government incentives and awards will be the result of entrepreneurial cooperation with a university. In the meantime, other SME stakeholders such as family members and also employees will surely benefit from and be satisfied with the establishment, growth and development of the SME. 


\subsubsection{The Consequences of Implementing the Model for Other Cooperation Stakeholders}

The cooperation of universities and SMEs also has other stakeholders. For a large number of the graduates of universities who are looking for work, government authorities are responsible for implementing job creation programs, and scientific and regional development will benefit greatly from the positive consequences of this cooperation in order to increase the productivity and enhance knowledge-based job creation, as well as reducing the unemployment rate.

\section{Summary and Conclusions}

As specified in the research results, there is currently no appropriate cooperation between the universities and the SMEs and, despite the efforts and desires of governmental managers in recent years, not much success has been obtained in this regard, and raising this issue has become a stereotypical and tedious topic among stakeholders. Neither of the parties see the need for cooperation with the other. Academics and, in a particular sense, faculty members are facing abundant involvement and, in order to promote their professional position, should move a path in which there is not necessarily much cooperation with SMEs. On the other hand, the managers/owners of SMEs have difficulties in recognizing their needs and problems, so that in finding the source of their problems they do not have a clear and accurate understanding about their current and future needs, and thus no desire to resolve these problems. Meanwhile, however, manager/owners prefer to meet their needs through ways other than universities that have less risk involved and stronger guarantees. They do not feel the need to cooperate with the universities (professors), because they do not have much trust in universities to resolve their problems, and they have had unsuccessful experiences in this regard. The solutions that have been presented in the past to create cooperation were not successful. Solutions have often focused on founding new knowledge-based academic companies through intermediary centers and institutions such as growth centers, science and technology parks, and research towns, which currently are not proper solutions for the huge volume of SMEs in the country, because they are governmental and they present an incomplete imitation of the models of other countries. In this research, in order to achieve entrepreneurship cooperation between universities and SMEs in our country, the emphasis must be on the formation of private intermediary companies, which themselves also benefit from cooperation. These companies, located in universities, by providing management and support, investment, business and commerce, intermediation and technology-facilitating services to academic stakeholders (professors, students, managers and employees) as well as industrial stakeholders (managers/owners, family members, and employees) provide the context and field of entrepreneurial cooperation among all stakeholders. Making the existing SMEs knowledge based through cooperation with universities is also among the duties of these companies. On the other hand, another solution is the establishment of new emerging knowledge-based companies by academics, within the framework of the law on the protection of knowledge-based companies and institutions in our country, which was approved in 2010. The university, as a support-oriented university, by supporting these companies completely, and modifying its regulations, also provides internal motivation for academic stakeholders to cooperate with these companies. Another solution that exists for entrepreneurial cooperation, obtained from the research data, is called the Jihad-based native model. In this model, the emphasis is placed on the identification and protection of particular individuals and with spiritual and motivations that are ready to sacrifice themselves to meet the needs of the country. Ultimately, we suggest that future research should present a model for selecting SMEs that has the necessary capabilities to cooperate with universities. We also suggest the compilation of strategic and operational programs by the agents of companies in the private sector, and also the investigation of legal barriers and problems in cooperation contracts.

Although this research tried to identify the elements and components of entrepreneurial cooperation between universities and SMEs, due to the extensive related topics, it was not possible to analyze each of these components in depth. Therefore, it is recommended that the following topics are studied separately or in connection with each other in further research: 
- Entrepreneurial cooperation models between universities and SMEs in different universities, divided into technical engineering and non-technical engineering universities.

- Entrepreneurial cooperation models between universities and SMEs, divided into small enterprises (up to 50 employees) and medium enterprises (from 50 to 100 employees).

- The relationship between the performance of each stakeholder (academic and SME stakeholders) with the success of entrepreneurial cooperation between universities and SMEs.

- The effect of the geographical location of universities and SMEs on the success of the entrepreneurial cooperation between them.

- The use of other research methods (methodologies), such as Social Network Analysis (SNA), that have been used in $[54,55]$.

- The impact of Information Systems (IS) and block chain technology on the development of cooperation between universities and SMEs (see [56]).

Author Contributions: Writing—original draft preparation, Y.M.; data curation, Y.M.; contributed to the revising and finalizing of the article, S.N. All authors have read and agreed to the published version of the manuscript.

Funding: This research received no external funding.

Acknowledgments: We would like to thank everyone (Appendix A) who participated in the interviews.

Conflicts of Interest: The authors declare no conflict of interest. 


\section{Appendix A}

Table A1. The characteristics of interviewees.

\begin{tabular}{|c|c|c|c|}
\hline Educational Level & Scientific/Executive Post & Date of Interview & Code of Interviewee \\
\hline Ph.D. & Vice-chancellor for Research and Technology of Iran Science and Technology University & 2016.07.23 & 30 \\
\hline Ph.D. & Research manager of Iran Science and Technology University & 2016.07 .23 & 31 \\
\hline Ph.D. & Incubator manager of Iran Science and Technology University & 2016.07 .23 & 33 \\
\hline Ph.D. & Manager of Scientific-Industrial Cooperation Office of Iran Science and Technology University & 2016.07.23 & 34 \\
\hline Ph.D. & Vice-chancellor of Railway Faculty of Iran Science and Technology University & 2016.11 .16 & 35 \\
\hline Ph.D. & Economy faculty member of Sharif University & 2016.12 .08 & 36 \\
\hline Ph.D. & Faculty member of a university & 2016.12.08 & 37 \\
\hline Ph.D. & Faculty member of Allameh Tabataba'i University & 2016.12.08 & 38 \\
\hline Ph.D. & The head of an innovation fund & 2016.12.08 & 40 \\
\hline M.A. & $\begin{array}{c}\text { Vice-chancellor of supporting knowledge enterprises, the knowledge enterprise office and } \\
\text { vice-president of science and technology companies }\end{array}$ & 2016.12.27 & 43 \\
\hline Ph.D. & Lecturer at Allameh Tabataba'i University & 2017.01.25 & 44 \\
\hline M.A. & Previous programming vice-chancellor of the Ministry of Industry, Mine and Trade/Ph.D. student & 2017.01.20 & 45 \\
\hline Ph.D. & $\begin{array}{l}\text { Previous head manager of Tehran municipality; current counsellor of the Ministry of Industry, } \\
\text { Mine and Trade }\end{array}$ & 2017.01.30 & 46 \\
\hline B.A. & $\begin{array}{c}\text { Teacher and member of the board of directors of Research and Development Committee of } \\
\text { Industries and Mines of Iran }\end{array}$ & 2017.03.13 & 47 \\
\hline B.A. & Marketing manager of Takab Ettesal company; producer of polyamine and polypill connections & 2017.02.19 & 48 \\
\hline B.A. & Marketing manager of Tekab Ettesal company & 2017.02.19 & 48 \\
\hline B.A. & Vice-chancellor of National Cooperative Union of Petrochemical Downstream Industry & 2017.02.19 & 49 \\
\hline Diploma & Director of plastic production company & 2017.02.20 & 50 \\
\hline B.A. & $\begin{array}{c}\text { Substitute and member of board of directors of a company; member of board of directors of the } \\
\text { industrial park of Nasirabad }\end{array}$ & 2017.02.20 & 51 \\
\hline B.A. & Vice-president of Morvarid Papyrus company & 2017.02 .20 & 52 \\
\hline
\end{tabular}


Table A1. Cont.

\begin{tabular}{|c|c|c|c|}
\hline Educational Level & Scientific/Executive Post & Date of Interview & Code of Interviewee \\
\hline M.A. & Research and development expert from Iran Nasb Niroo company & 2017.02.20 & 53 \\
\hline B.A. & Sale manager of Arian lift company & 2017.02.20 & 54 \\
\hline Diploma & Vice-president of the board of directors of Sabalan plastic production company & 2017.02.20 & 55 \\
\hline B.A. & Director of Teknometa company & 2017.02.20 & 56 \\
\hline M.A. & Staff department manager of a university & 2017.02.21 & 57 \\
\hline B.A. & Quality control manager of Shayan Valve company & 2017.02.22 & 58 \\
\hline B.A. & Sale manager of Tarahan Furniture company & 2017.02.22 & 59 \\
\hline B.A. & Sale manager of Aria Electronic company & 2017.02.22 & 60 \\
\hline B.A. & The head of the board of directors of Avisa Pak company & 2017.02.22 & 61 \\
\hline M.A. & Small industries' chancellor of industrial parks of Tehran & 2017.02.22 & 62 \\
\hline B.A. & $\begin{array}{l}\text { Previous manager of science and technology higher education center/vice-president of a } \\
\text { production company }\end{array}$ & 2017.03.01 & 63 \\
\hline B.A. & Expert from Assoplast & 2017.02.22 & 64 \\
\hline M.A. & Management development vice-chancellor-Industry, Mine and Trade office of Lorestan & 2017.03.25 & 65 \\
\hline M.A. & Head manager of the standards of Lorestan province & 2017.03.25 & 66 \\
\hline M.A. & Vice-president of industrial block production company (knowledge enterprise) & 2017.03.26 & 68 \\
\hline M.A. & Manager of investment of Industry, Mine and Trade of Lorestan province & 2017.03.25 & 69 \\
\hline M.A. & Vice-president of industrial parks in Lorestan province & 2017.03.26 & 70 \\
\hline B.A. & Accountant at Boroujerd industrial park & 2017.03.28 & 71 \\
\hline M.A. & $\begin{array}{c}\text { Manager of industrial offices of Industry, Mine and Trade offices of Boroujerd/Ph.D. student of } \\
\text { industrial engineering }\end{array}$ & 2017.03.28 & 72 \\
\hline Ph.D. & The head of workshops, laboratories and the library of Ayatollah Boroujerdi University & 2017.04.03 & 73 \\
\hline
\end{tabular}


Table A2. The results obtained from axial coding.

\begin{tabular}{|c|c|c|}
\hline Axial Coding (Concepts) & Axial Coding (Subcategories) & Selective Coding (Main Categories) \\
\hline Individual characteristics (internal motivation, interest, etc.) & \multirow{3}{*}{$\begin{array}{l}\text { Individual goals and motivation in the } \\
\text { university }\end{array}$} & \multirow{11}{*}{$\begin{array}{l}\text { Causal conditions (entrepreneurial } \\
\text { cooperation goals and motivations) }\end{array}$} \\
\hline Material goals (income, etc.) & & \\
\hline Immaterial goals (professional responsibility, etc.) & & \\
\hline $\begin{array}{l}\text { Organizational goals (social responsibility, organizational responsibility, } \\
\text { wealth, etc.) }\end{array}$ & $\begin{array}{l}\text { Organizational goals and motivations of the } \\
\text { university }\end{array}$ & \\
\hline Individual characteristics (internal motivation, interest, etc.) & \multirow{3}{*}{ Individual goals and motivation in the SME } & \\
\hline Material goals (income, etc.) & & \\
\hline Immaterial goals (professional responsibility, etc.) & & \\
\hline SME growth & \multirow{2}{*}{ Organizational goals and motivation of the SME } & \\
\hline SME survival & & \\
\hline Incentives resulting from rules and regulations & \multirow{2}{*}{ Goals and motivation of external factors } & \\
\hline Pursuing cooperation trustees & & \\
\hline Entrepreneurial characteristics of stakeholders in the university & \multirow{3}{*}{$\begin{array}{l}\text { Individual factors in the university for } \\
\text { cooperation }\end{array}$} & \multirow{12}{*}{$\begin{array}{l}\text { Category orientation (entrepreneurial } \\
\text { cooperation between the university and } \\
\text { the SMEs) }\end{array}$} \\
\hline Demand and will of academic stakeholders for cooperation & & \\
\hline Analysis of stakeholders in the university & & \\
\hline Useful and applied research of the university & \multirow{6}{*}{$\begin{array}{l}\text { Organizational factors of the university for } \\
\text { cooperation }\end{array}$} & \\
\hline Entrepreneurship and commercialization of the technology of university & & \\
\hline Entrepreneurial education of the university & & \\
\hline Entrepreneurial program and structure of the university & & \\
\hline Professional management of the university & & \\
\hline Capabilities and facilities of the university & & \\
\hline Entrepreneurial characteristics of stakeholders in the SME & \multirow{3}{*}{ Individual factors of the SME for cooperation } & \\
\hline Demand and will of SME stakeholders for cooperation & & \\
\hline Analysis of stakeholders in the SME & & \\
\hline
\end{tabular}


Table A2. Cont.

\begin{tabular}{|c|c|c|}
\hline Axial Coding (Concepts) & Axial Coding (Subcategories) & Selective Coding (Main Categories) \\
\hline Problems and needs of SME & \multirow{3}{*}{$\begin{array}{l}\text { Organizational factors of the SME for } \\
\text { cooperation }\end{array}$} & \\
\hline Entrepreneurial program and structure of the SME & & \\
\hline Professional management in the SME & & \\
\hline $\begin{array}{l}\text { Administrative problems (administrative corruption, administrative } \\
\text { bureaucracy, etc.) }\end{array}$ & \multirow{4}{*}{ Macro environmental problems } & \multirow{7}{*}{$\begin{array}{l}\text { Background conditions (environmenta } \\
\text { issues and entrepreneurial cooperation } \\
\text { ecosystem) }\end{array}$} \\
\hline Cultural problems (work culture, the culture of looking outside, etc.) & & \\
\hline Political problems (politicizing, etc.) & & \\
\hline Economic problems (instability, imports, etc.) & & \\
\hline Guild societies and related institutions and centers & \multirow{3}{*}{ Cooperation ecosystem } & \\
\hline Protecting cooperation & & \\
\hline Multilateral cooperation & & \\
\hline $\begin{array}{l}\text { Difficulties and barriers of cooperation (lack of feeling/distrust/cultural } \\
\text { differences/differences of opinion/previous unsuccessful } \\
\text { experiences/abundant involvements) }\end{array}$ & \multirow{2}{*}{ Cooperation context and background } & \multirow{9}{*}{$\begin{array}{l}\text { Mediating conditions (entrepreneurial } \\
\text { cooperation context and infrastructure) }\end{array}$} \\
\hline $\begin{array}{l}\text { Cooperation threats (creating competition/lack of stakeholder } \\
\text { participation/incomplete cooperation ecosystem cycle) }\end{array}$ & & \\
\hline Budget & \multirow{4}{*}{ Cooperation requirements } & \\
\hline Facilities & & \\
\hline $\begin{array}{l}\text { Communicational mechanisms (informal communications/informing } \\
\text { systems) }\end{array}$ & & \\
\hline $\begin{array}{l}\text { Legal issues (cooperation contracts/ownership/stock/commitments and } \\
\text { guarantees) }\end{array}$ & & \\
\hline $\begin{array}{l}\text { Beginning cooperation (creative methods, beginning from the university } \\
\text { and from a few other locations, etc.) }\end{array}$ & \multirow{3}{*}{ Cooperation process } & \\
\hline Stakeholders' participation in the cooperation & & \\
\hline Need and demand mechanism in the cooperation & & \\
\hline
\end{tabular}


Table A2. Cont.

\begin{tabular}{|c|c|c|}
\hline Axial Coding (Concepts) & Axial Coding (Subcategories) & Selective Coding (Main Categories) \\
\hline Agent (intermediary) in the private sector & \multirow{2}{*}{ Strategies related to the private sector } & \multirow{4}{*}{$\begin{array}{l}\text { Strategies (entrepreneurial cooperation } \\
\text { strategies) }\end{array}$} \\
\hline Knowledge based companies & & \\
\hline Jihad-based native model & \multirow{2}{*}{ Strategies related to the non-private sector } & \\
\hline Support oriented university & & \\
\hline Material consequences (increasing income-job creation, etc.) & \multirow{2}{*}{$\begin{array}{l}\text { Cooperation consequences for individual factors } \\
\text { of the university }\end{array}$} & \multirow{10}{*}{$\begin{array}{l}\text { Consequences (entrepreneurial } \\
\text { cooperation consequences) }\end{array}$} \\
\hline $\begin{array}{l}\text { Immaterial consequences (scientific growth/professional } \\
\text { responsibility/meeting internal requirements, etc.) }\end{array}$ & & \\
\hline Material consequences (creating stable incomes, etc.) & \multirow{2}{*}{$\begin{array}{l}\text { Cooperation consequences for organizational } \\
\text { factors of the university }\end{array}$} & \\
\hline $\begin{array}{l}\text { Immaterial consequences (professional and social responsibility/meeting } \\
\text { stakeholders appropriately, etc.) }\end{array}$ & & \\
\hline $\begin{array}{l}\text { Material consequences (increasing income/maintaining income level, } \\
\text { etc.) }\end{array}$ & \multirow{2}{*}{$\begin{array}{l}\text { Cooperation consequences for individual factors } \\
\text { of the SME }\end{array}$} & \\
\hline $\begin{array}{l}\text { Immaterial consequences (professional responsibility/meeting internal } \\
\text { requirements, etc.) }\end{array}$ & & \\
\hline $\begin{array}{l}\text { Material consequences (producing wealth and value added, survival, } \\
\text { development, and growth of the SME) }\end{array}$ & \multirow{2}{*}{$\begin{array}{l}\text { Cooperation consequences for organizational } \\
\text { factors of the SME }\end{array}$} & \\
\hline Immaterial consequences, appropriate accountability of the stakeholders & & \\
\hline Graduate job creation & \multirow{2}{*}{$\begin{array}{l}\text { Cooperation consequences for other } \\
\text { stakeholders }\end{array}$} & \\
\hline $\begin{array}{l}\text { Economic development and growth for the country (entrepreneurship } \\
\text { revolution) }\end{array}$ & & \\
\hline
\end{tabular}




\section{References}

1. Dalmarco, G.; Hulsink, W.; Blois, G.V. Creating entrepreneurial universities in an emerging economy: Evidence from Brazil. Technol. Forecast. Soc. Chang. 2018, 135, 99-111. [CrossRef]

2. Guimon, J. Promoting University-Industry Collaboration in Developing Countries; The Innovation Policy Platform, World Bank: New York, NY, USA, 2013.

3. Styhre, A.; Lind, F. The softening bureaucracy: Accommodating new research opportunities in the entrepreneurial university. Scand. J. Manag. 2010, 26, 107-120. [CrossRef]

4. Vega-Jurado, J.; Fernandez-de-Lucio, I.; Huanca, R. University-industry relations in Bolivia: Implications for university transformations in Latin America. High Educ. 2007, 56, 205-220. [CrossRef]

5. Secundo, G.; Perez, S.E.; Martinaitis, Z.; Leitner, K.H. An Intellectual Capital framework to measure universities third mission activities. Technol. Forecast. Soc. Chang. 2017, 123, 229-239. [CrossRef]

6. Ssebuwufu, J.; Ludwick, T.; Beland, M. Strengthening University-Industry Linkages in Africa: A Study on Institutional Capacities and Gaps; Association of African Universities (AAU): Accra, Ghana, 2012.

7. Eun, J.-H.; Lee, K.; Wu, G. Explaining the "university-run entreprises" in China: A theoretical framework for University-Industry Relationship in developing countries and its application to China. Res. Pol. 2006, 35, 1329-1346. [CrossRef]

8. Rajalo, S.; Vadi, M. University-industry innovation collaboration: Reconceptualization. Technovation 2017, 62, 42-54. [CrossRef]

9. Perkmano, M.; Walsh, K. University-Industry relationship and open innovation: Towards a research agenda. Int. J. Manag. Rev. 2007, 9, 259-280. [CrossRef]

10. Ankrah, S.; Omar, A.T. Universities-industry collaboration: A systematic review. Scand. J. Manag. 2015, 31, 387-408. [CrossRef]

11. Leydesdorff, L.; Park, H.W.; Lengyel, B. A routine for measuring synergy in university-industly-government relations: Mutual information as a Triple-Helix and Quadruple-Helix indicator. Scientometrics 2013, 99, $27-35$. [CrossRef]

12. Etzkowitz, H. Innovation in innovation: The triple helix of university-industry-government relations. Soc. Sci. Inf. 2003, 42, 293-337. [CrossRef]

13. Faisal, R.; Chong, A.L.; Voon Yee, A.S. Systematic review of sustainable knowledge transfer process in government-industry-academia consortium. Asian J. Innov. Pol. 2017, 6, 295-312.

14. Zavale, N.C.; Macamo, E. How and what knowledge do universities and academics transfer to industry in African low-income countries? Evidence from the stage of university-industry linkages in Mozambique. Int. J. Educ. Dev. 2016, 49, 247-261. [CrossRef]

15. Kruss, G.; Adeoti, J.O.; Nabudere, D. Bracing for change: Making universities and firms partners for innovation in sub-Saharan Africa. In Developing National Systems of Innovation; Albuquerque, E., Lee, K., Suzigan, W., Kruss, G., Eds.; Edward Elgar Publishing: Cheltenham, UK, 2015; pp. 31-54. Available online: https://www.elgaronline.com/view/edcoll/9781784711092/9781784711092.00009.xml (accessed on 30 January 2015).

16. Garousi, V.; Eskandar, M.M.; Herkiloglu, K. Industry-academia collaborations in software testing: Experience and success stories from Canada and Turkey. Softw. Qual. J. 2016, 25, 1091-1143. [CrossRef]

17. Banal-Estanol, A.; Macho-Stadler, I.; Perez-Castrillo, D. Endogenous matching in university-industry collaboration: Theory and empirical evidence from the United Kingdom. Manag. Sci. 2018, 64, 1591-1608. [CrossRef]

18. Filippetti, A.; Savona, M. University-industry linkages and academic engagements: Individual behaviours and firms' barriers. Introduction to the special section. J. Technol. Trans. 2017, 42, 719-729. [CrossRef]

19. Arza, V.; Carattoli, M. Personal ties in university-industry linkages: A case-study from Argentina. J. Technol. Trans. 2016, 42, 814-840. [CrossRef]

20. Silas, U.N.; Wim, G. Context perspective on University-Industry Collaboration processes: A systematic review of literature. J. Clean. Prod. 2020, 258, 120861.

21. David, P.; Nick, C.; Julienne, S. Universities, SMEs and Innovation Frameworks Think Global, Act Local? Ind. High. Educ. 2009, 23, 79-89. 
22. Nouri, S.; Moradi, Y. Investigating the methods of interaction and cooperation between university and small-and medium-sized enterprises. In Proceedings of the Second International Conference on Management, Dynamic Accounting and Auditing, Tehran, Iran, 25 May 2017.

23. Lin, J.Y. Alancing industry collaboration and academic innovation: The contingent role of collaborationspecific attributes. Technol. Forecast. Soc. Chang. 2017, 123, 216-228. [CrossRef]

24. Bagherinejad, J. The system of the university-industry communication for technological developments in Iran: Mechanisms and suggestions. Policy Sci. Technol. 2008, 1, 1-14.

25. Katila, R.; Mang, P.Y. Exploiting technological opportunities: The timing of collaborations. Res. Policy 2003, 32, 317-332. [CrossRef]

26. Ansari, R. Technological cooperation: Key concepts and success factors. Seas. Spec. J. Technol. Growth 2012, 8, 30 .

27. Elyasi, M.; Kazzazi, A.; Mohammadi, M. Investigating the effect of institutional environment arrangement on the effectiveness of technological cooperation in aerospace industries of the country with an emphasis on the role of the intermediary organizations. J. Manag. Improv. 2011, 5, 139-158.

28. Rafsanjaninejad, S. Instruments for Advancing the Technological Collaborations and Knowledge-Based Economy, The Statute Book of the Technological Attachment. 2017. Available online: http://www.npps.ir/ArticlePreview. aspx?id=121920 (accessed on 6 August 2017).

29. Aghajani, H.A.; Samadi, M.; Yahya Tabar, F. Seven mutual expectations of the university and industry. In Proceedings of the First National Conference on the Research and Technology Management, Tehran, Iran, 22 December 2010.

30. Shafiei, M.; Yazdanian, V. Conceptual development of the relationship between industry and university: From operation-based solutions to institutional-driven solutions. Seas. J. Eng. Educ. Iran. 2008, 9, 81-110.

31. Hanafizadeh, P.; Salami, R.; Rowhani Tabataba'ei, M. Determining the factors influencing the selection of the inter-entities cooperation method (case study: Iran's information technology entities. J. Knowl. Manag. 2006, 74, 3-18.

32. Bjerregaard, T. Universities-industry collaboration strategies: A micro-level perspective. Eur. J. Innov. Manag. 2009, 12, 161-176. [CrossRef]

33. Bekkers, R.; Freitas, I.M.B. Analysing knowledge transfer channels between universities and industry: To what degree do sectors also matter? Res. Policy 2008, 37, 1837-1853. [CrossRef]

34. Karlsson, J.; Booth, S.; Odenrick, P. Academics' strategies and obstacles in achieving collaboration between universities and SMEs. Tert. Educ. Manag. 2007, 13, 187-201. [CrossRef]

35. Buganza, T.; Colombo, G.; Landoni, P. Small and medium enterprises' collaborations with universities for new product development: An analysis of the different phases. J. Small Bus. Enterp. Dev. 2014, 21, 69-86. [CrossRef]

36. Chiesa, V. RED Strategy and Organization: Managing Technical Change in Dynamic Contexts; Imperial College Press: River Edge, NJ, USA, 2001; Chapter 2, pp. 21-27, pp. 39-42; Chapter 7, pp. 235-266.

37. Izushi, H. Impact of the length of relationships upon the use of research institutes by SMEs. Res. Policy 2003, 32, 771-788. [CrossRef]

38. Shafiei, M. The relationship between the university and industry: Essential barriers and developmental solutions. In Proceedings of the 8th General Conference on the Cooperation between the Government, University and Industry for the National Development, Tehran, Iran, 22 September 2004.

39. Jones, J.; De Zubielqui, G.C. Doing well by doing good: A study of university-industry interactions, innovationess and firm performance in sustainability-oriented Australian SMEs. Technol. Forecast. Soc. Chang. 2017, 123, 262-270. [CrossRef]

40. Fukugawa, N. Characteristics of knowledge interactions between universities and small firms in Japan. Int. Small Bus. J. 2005, 23, 379-401. [CrossRef]

41. Berbegal-Mirabent, J.; García, J.L.; Ribeiro-Soriano, D.E. University-industry partnerships for the provision of R\&D services. J. Bus. Res. 2015, 68, 1407-1413.

42. Plechero, M. The Role of Local Universities in Improving Traditional SMEs Innovative Performances: The Veneto Region Case; No. 2009/11; Lund University, CIRCLE-Center for Innovation, Research and Competences in the Learning Economy: Lund, Sweden, 2009. Available online: https:/econpapers.repec.org/paper/hhslucirc/ 2009_5f011.htm (accessed on 1 November 2009). 
43. Garcia-Perez-de-Lema, D.; Madrid-Guijarro, A.; Martin, D.P. Influence of university-firm governance on SMEs innovation and performance levels. Technol. Forecast. Soc. Chang. 2017, 123, 250-261. [CrossRef]

44. Fontana, R.; Geuna, A.; Matt, M. Factors affecting university-industry R\&D projects: The importance of searching, screening and signaling. Res. Policy 2006, 35, 309-323.

45. Mohnen, P.; Hoareau, C. What type of enterprise forges close links with universities and government labs? Evidence from CIS 2. Manag. Decis. Econ. 2003, 24, 133-145. [CrossRef]

46. Tether, B.S. Who co-operates for innovation, and why: An empirical analysis. Res. Policy 2002, 31, 947-967. [CrossRef]

47. Dehghani, A.; Hosseini, H. Barriers and executive challenges in the process of technological collaborations (case study: Nanotechnology field). J. Indust. Technol. Dev. 2017, 15, 59-64.

48. Comacchio, A.; Bonesso, S.; Pizzi, C. Boundary spanning between industry and university: The role of Technology Transfer Centres. J. Technol. Trans. 2012, 37, 943-966. [CrossRef]

49. Chau, V.S.; Gilman, M.; Serbanica, C. Aligning university-industry interactions: The role of boundary spanning in intellectual capital transfer. Technol. Forecast. Soc. Chang. 2017, 123, 199-209. [CrossRef]

50. Goduscheit, R.C.; Knudsen, M.P. How Barriers to Collaboration Prevent Progress in Demand for Knowledge: A Dyadic Study of Small and Medium-Sized Firms, Research and Technology Organizations and Universities. Creat. Innov. Manag. 2015, 24, 29-54. [CrossRef]

51. Temel, S.; Scholten, V.; Akdeniz, R.C.; Fortuin, F.; Omta, O. University-industry collaboration in Turkish SMEs: Investigation of a U-shaped relationship. Int. J. Enterpren Innov. Manag. 2013, 14, 103-115. [CrossRef]

52. Gall, M.; Gall, J.; Borg, W. Educational Research: An Introduction; Pearson Education: New York, NY, USA, 2003.

53. Strauss, A.; Corbin, J. Basics of Qualitative Research: Grounded Theory Procedures and Techniques, 4th ed.; Sage Publication: Washington, DC, USA, 2015.

54. Valeri, M.; Baggio, R. Social network analysis: Organizational implications in tourism management. Int. J. Organ. Anal. 2020. [CrossRef]

55. Valeri, M.; Baggio, R. Italian tourism intermediaries: A social network analysis exploration. Curr. Issues Tour. 2020. [CrossRef]

56. Valeri, M.; Baggio, R. A critical reflection on the adoption of blockchain in tourism. Inf. Technol. Tour. 2020. [CrossRef]

Publisher's Note: MDPI stays neutral with regard to jurisdictional claims in published maps and institutional affiliations.

(C) 2020 by the authors. Licensee MDPI, Basel, Switzerland. This article is an open access article distributed under the terms and conditions of the Creative Commons Attribution (CC BY) license (http://creativecommons.org/licenses/by/4.0/). 